\title{
МЛЭ твёрдых растворов GaPxAs1-x на вицинальных подложках: влияние отклонения на состав пленок
}

Е.А. Емельянов, М.О. Петрушков, И.Д. Лошкарев, А.В. Васев, Б.Р. Семягин, М.А. Путято, В.В. Преображенский

ИФП СО РАН, Новосибирск, 630099, пр. ак. Лаврентьева 13

тел: (383)333-19-67, факс: (383)333-75-02, эл. почта: е2a@isp.nsc.ru

DOI 10.34077/RCSP2021-38

Твёрдые растворы $G a P_{x} A s_{1-x}$ находят широкое применение для создания солнечных элементов, транзисторов с высокой подвижностью электронов и лазеров. Выращивание таких твёрдых растворов с заданным составом является сложной научно-технологической задачей. Это обусловлено тем, что формирование состава $G a P_{x} A s_{1-x}$ в подрешётке пятой группы зависит от большого числа параметров роста, таких как температура $\left(T_{\mathrm{s}}\right)$, величины и соотношения потоков атомов галлия $\left(J_{I I I}\right)$, молекул мышьяка $\left(J_{A s}\right)$ и фосфора $\left(J_{P}\right)$. Известно [1,2], что состав твёрдых растворов, таких как $G a A s_{x} S b_{1-x}$ и $\operatorname{In} A s_{x} S b_{1-x}$, зависит от величины угла разориентации подложки $[1,2]$. Таким образом, при создании гетероструктур на базе слоёв твёрдого раствора $G a P_{x} A s_{1-x}$, следует учитывать эту зависимость.

В данной работе было исследовано влияние отклонения подложки $G a A s$ от сингулярной грани (100) в направлении [110] на $0^{\circ}, 1^{\circ}, 2^{\circ}, 3^{\circ}, 5^{\circ}$ и $7^{\circ}$ на состав твёрдых растворов $G a P_{x} A s_{1-x}$. Слой твёрдого раствора выращивался одновременно на положках всех ориентаций. Использовались потоки молекул $\mathrm{As}_{2}$ и $\mathrm{P}_{2}$, скорость роста составляла $1 \mathrm{MC} / \mathrm{c}, \mathrm{T}_{\mathrm{s}}=500^{\circ} \mathrm{C}$, толщина плёнки - 1 мкм. Выращенные образцы были исследованы методом высокоразрешающей рентгеновской дифрактометрии.

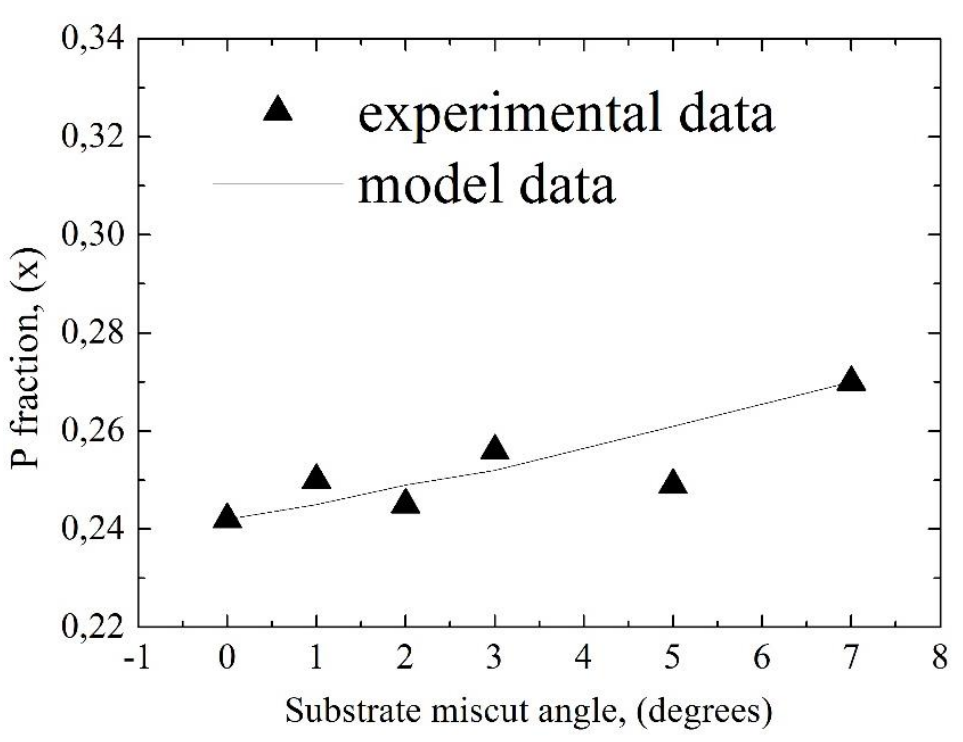

На рисунке представлена зависимость состава твёрдого раствора $G a P_{x} A s_{1-x}$ от угла отклонения подложки $G a A s(001)$. Доля фосфора $x$ монотонно возрастает от 0.24 при $0^{\circ}$, до 0.27 при $7^{\circ}$.

Полученные результаты были объяснены в рамках разработанной модели формирования состава твердых растворов замещения по пятой группе соединений $\mathrm{A}^{\mathrm{III}} \mathrm{B}^{\mathrm{V}}$.

Увеличение угла разориентации подложки приводит к росту плотности террас в направлении отклонения. При этом скорость обновления краёв террас уменьшается и увеличивается время экспозиции вновь сформированного края террасы в потоках молекул $\mathrm{As}_{2}$ и $\mathrm{P}_{2}$. В течении этого времени (до прихода очередного фронта роста) происходит изменение состава анионного слоя поверхности, сформированного на фронте роста, за счет адсорбционно-десорбционных процессов. В результате этих процессов состав анионного слоя изменяется в сторону увеличения доли фосфора.

\section{Лumepamypa}

[1] K. Mochizuki, T. Nishinaga // Jpn. J. Appl. Phys. 1988. 27, p. 1585.

[2] Е.А. Емельянов, А.В. Васев и др. // ФТП. 2019. Т.53, вып.4. С.513-519. 